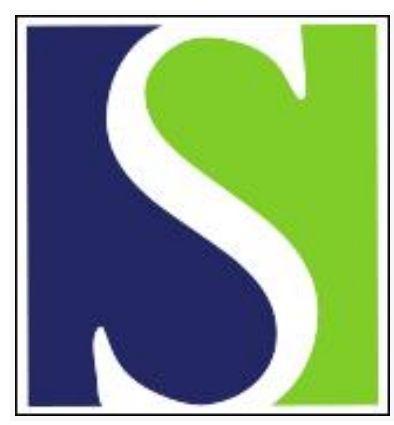

Scand J Work Environ Health 1984;10(6):467-469

https://doi.org/10.5271/sjweh.2297

Issue date: Dec 1984

\title{
Complaints of insomnia in different occupations.
}

by Partinen M, Eskelinen L, Tuomi K

This article in PubMed: www.ncbi.nlm.nih.gov/pubmed/6535249

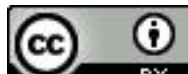




\title{
Complaints of insomnia in different occupations
}

\author{
by Markku Partinen, MD, Leena Eskelinen, MA, Kaija Tuomi, LSocSc ${ }^{1}$
}

\begin{abstract}
PARTINEN M, ESKELINEN L, TUOMI K. Complaints of insomnia in different occupations. Scand $J$ Work Environ Health 10 (1984) 467-469. Complaints of insomnia were inquired about in a questionnaire survey of 6268 persons ( 2801 men, 3467 women, mean age 50.5 years, range $45-57$ years) in 40 different occupational groups. Among bus drivers $18.9 \%$ complained of having rather or very much difficulty falling asleep. Among female cleaners, male teachers, male directors, and male physicians the respective percentages were $18.8,18.0,3.7$, and 4.9. Disturbed nocturnal sleep was complained of the most often by male laborers $(28.1 \%$ waking up at least three times a night), female cleaners $(26.6 \%)$ and female hospital aides $(26.4 \%$ ). Disturbed nocturnal sleep was rare among male physicians $(1.6 \%)$, male directors $(7.4 \%)$, female head nurses $(8.9 \%)$, and female social workers $(9.4 \%)$. Complaints of waking up too early in the morning were the most common among female laborers $(13.2 \%$ often or always), male construction workers $(9.1 \%)$, and female cleaners $(8.4 \%)$ ). They were rare among male physicians $(1.6 \%)$, male directors $(1.8 \%)$, nurses in outpatient wards $(1.2 \%)$, and female bathers $(2.0 \%)$. Sleeping pills were used the most frequently by male gardeners $(7.1 \%$ were frequent or habitual users), female social office workers $(5.8 \%)$, and male construction workers $(5.4 \%)$. Some aspects of work which could explain the differences are discussed.
\end{abstract}

Key terms: sleep disorders.

Irregular work times, shift work, lack of sleep, insomnia, and specific sleep disorders, such as narcolepsy or sleep apnea syndrome, may reflect harmfully on alertness at work. In this study we have studied the complaints of insomnia among workers in different occupations.

\section{Subjects and methods}

The study was a part of a large epidemiologic survey concentrating mainly on the grounds for the retirement age in municipal occupations. The base population consisted of 7344 adult municipal employees in 40 different occupations. There were 2801 men (mean age 50.5 years, range $45-57$ years) and 3467 women (mean age 50.4 years, range $45-57$ years). There were some clearly female occupations (nurse, cleaner, etc) and some nearly pure male occupations (bus driver, fireman, etc). No significant differences existed in the distributions of age between the occupations.

A postal questionnaire study was carried out to measure various health-related variables. The baseline characteristics of the study have been documented in detail elsewhere (1). The response rate was $85.3 \%$. All retired and unemployed persons were excluded, and the responses of 6268 persons were used in these analyses.

1 Institute of Occupational Health, Helsinki, Finland.

Reprint requests to: Dr M Partinen, Institute of Occupational Health, Haartmaninkatu 1, SF-00290 Helsinki, Finland.
As concerned difficulties to get to sleep, the respondents were asked to rate, on a five-point scale, whether they generally fell asleep "very easily," "rather easily," "not so easily but not with difficulty," "with rather much difficulty," or "with much difficulty." They were asked if they usually slept "without waking up at night," "with waking once during the night," "with waking two times a night," "with waking three to four times a night," or "with waking up several times a night with disrupted nocturnal sleep." They were asked whether, in the near past they had awakened too early in the morning without being able to fall asleep again "ever," "rather rarely," "sometimes," "rather often," or "often." They were also asked whether they used sleeping pills "never," "sometimes," or "often or always."

\section{Results}

Having difficulty falling asleep was as common among the women (12.2\%) as among the men $(12.1 \%)$. The occupations in which the complaint was the most common or the rarest are listed in table 1. Difficulty falling asleep was complained of frequently by male bus drivers, female cleaners, and male teachers.

Disturbed nocturnal sleep (waking up usually at least three times a night) was complained of by $17.5 \%$ of all women and $15.7 \%$ of all men. The occurrence of disturbed nocturnal sleep in some occupations is shown in table 2 .

Waking up too early in the morning without being able to fall asleep again was complained of nearly as 
Table 1. Occupations for which the complaint of rather or very much difficulty falling asleep was frequent or rare. ${ }^{a}$

\begin{tabular}{lccccc}
\hline \multicolumn{2}{c}{ Complaint frequent } & & \multicolumn{2}{c}{ Complaint rare } \\
\cline { 5 - 6 } Occupation & $\begin{array}{c}\text { Number of } \\
\text { subjects }\end{array}$ & $\begin{array}{c}\text { Percentage } \\
\text { with complaint }\end{array}$ & Occupation & $\begin{array}{c}\text { Number of } \\
\text { subjects }\end{array}$ & $\begin{array}{c}\text { Percentage } \\
\text { with complaint }\end{array}$ \\
\hline Males & & & & & \\
Bus drivers & 64 & 18.9 & Directors & 162 & 3.7 \\
Teachers & 78 & 18.0 & Physicians & 61 & 8.9 \\
Mental health nurses & 59 & 17.4 & Electricians & 163 & 8.5 \\
Laborers & 89 & 15.7 & & 90 & 8.9 \\
Females & 202 & 18.8 & Head nurses & 102 & 7.8 \\
Cleaners & 93 & 15.1 & Social workers & 85 & 8.2 \\
Construction workers & 81 & 14.8 & Nurses in outpatient wards & 260 & 8.2 \\
Dentists & 277 & 14.4 & Mental health nurses & 96 & 9.4 \\
Practical nurses & & &
\end{tabular}

a Among the total population the complaint was reported by $12.1 \%$ of the men and $12.2 \%$ of the women.

Table 2. Occupations for which the complaint of waking up at least three times per night was frequent or rare. ${ }^{2}$

\begin{tabular}{|c|c|c|c|c|c|}
\hline \multicolumn{3}{|c|}{ Complaint frequent } & \multicolumn{3}{|c|}{ Complaint rare } \\
\hline Occupation & $\begin{array}{l}\text { Number of } \\
\text { subjects }\end{array}$ & $\begin{array}{c}\text { Percentage } \\
\text { with complaint }\end{array}$ & Occupation & $\begin{array}{l}\text { Number of } \\
\text { subjects }\end{array}$ & $\begin{array}{c}\text { Percentage } \\
\text { with complaint }\end{array}$ \\
\hline \multicolumn{6}{|l|}{ Males } \\
\hline $\begin{array}{l}\text { Laborers } \\
\text { Gardeners } \\
\text { Garpenters } \\
\text { Construction workers }\end{array}$ & $\begin{array}{r}89 \\
98 \\
145 \\
201\end{array}$ & $\begin{array}{l}28.1 \\
23.5 \\
22.2 \\
20.9\end{array}$ & $\begin{array}{l}\text { Physicians } \\
\text { Directors } \\
\text { Teachers } \\
\text { Mental health nurses }\end{array}$ & $\begin{array}{r}61 \\
162 \\
78 \\
69\end{array}$ & $\begin{array}{r}1.6 \\
7.4 \\
7.8 \\
12.8\end{array}$ \\
\hline \multicolumn{6}{|l|}{ Females } \\
\hline $\begin{array}{l}\text { Cleaners } \\
\text { Hospital aides } \\
\text { Construction workers } \\
\text { Kitchen helpers }\end{array}$ & $\begin{array}{r}202 \\
239 \\
93 \\
184\end{array}$ & $\begin{array}{l}26.6 \\
26.4 \\
26.1 \\
25.9\end{array}$ & $\begin{array}{l}\text { Head nurses } \\
\text { Social workers } \\
\text { Ward nurses } \\
\text { Dentists }\end{array}$ & $\begin{array}{r}102 \\
85 \\
170 \\
81\end{array}$ & $\begin{array}{r}8.9 \\
9.4 \\
9.4 \\
10.0\end{array}$ \\
\hline
\end{tabular}

a Among the total population the complaint was reported by $15.7 \%$ of the men and $17.5 \%$ of the women.

Table 3. Occupations for which the complaint of waking up too early without being able to fall asleep again (often or always) was frequent or rare. ${ }^{a}$

\begin{tabular}{|c|c|c|c|c|c|}
\hline \multicolumn{3}{|c|}{ Complaint frequent } & \multicolumn{3}{|c|}{ Complaint rare } \\
\hline Occupation & $\begin{array}{l}\text { Number of } \\
\text { subjects }\end{array}$ & $\begin{array}{c}\text { Percentage } \\
\text { with complaint }\end{array}$ & Occupation & $\begin{array}{l}\text { Number of } \\
\text { subjects }\end{array}$ & $\begin{array}{c}\text { Percentage } \\
\text { with complaint }\end{array}$ \\
\hline \multicolumn{6}{|l|}{ Males } \\
\hline $\begin{array}{l}\text { Construction workers } \\
\text { Laborers } \\
\text { Construction supervisors } \\
\text { Gardeners }\end{array}$ & $\begin{array}{r}201 \\
89 \\
185 \\
98\end{array}$ & $\begin{array}{l}9.1 \\
8.1 \\
7.6 \\
7.3\end{array}$ & $\begin{array}{l}\text { Physicians } \\
\text { Directors } \\
\text { Electricians } \\
\text { Carpenters }\end{array}$ & $\begin{array}{r}61 \\
162 \\
163 \\
145\end{array}$ & $\begin{array}{l}1.6 \\
1.8 \\
1.9 \\
2.1\end{array}$ \\
\hline \multicolumn{6}{|l|}{ Females } \\
\hline $\begin{array}{l}\text { Construction workers } \\
\text { Cleaners } \\
\text { Gardeners } \\
\text { Kitchen helpers }\end{array}$ & $\begin{array}{r}93 \\
202 \\
57 \\
184\end{array}$ & $\begin{array}{l}13.2 \\
8.4 \\
7.1 \\
6.5\end{array}$ & $\begin{array}{l}\text { Nurses in outpatient wards } \\
\text { Bathers } \\
\text { Ward nurses } \\
\text { Domestic helpers }\end{array}$ & $\begin{array}{l}260 \\
154 \\
170 \\
346\end{array}$ & $\begin{array}{l}1.2 \\
2.0 \\
2.3 \\
2.9\end{array}$ \\
\hline
\end{tabular}

a Among the total population the complaint was reported by $4.9 \%$ of the men and $4.5 \%$ of the women.

often by women $(4.5 \%)$ as by men $(4.9 \%)$. Early morning awakening was common among female and male construction workers (table 3).

According to the subjects' responses sleeping pills were used often or always by $2.3 \%$ of the women and $2.9 \%$ of the men. They were used the most frequently by male gardeners $(7.1 \%$ were frequent or habitual users), female social office workers $(5.8 \%)$, and male construction workers (5.4\%). Female mental health nurses used sleeping pills less than women in other types of nursing. Of female mental health nurses $8.2 \%$ had used sleeping pills at least sometimes, while the corresponding percentage for other female nurses was $19.9 \%$.

\section{Discussion}

In this study clear differences in the occurrence of insomnia were observed between various occupations. 
This finding differs from those of a recent study in the Houston Metropolitan Area of the United States (2). In that American survey the questions were posed in a very similar way, but the classification of occupations into only three main groups (office and sales, skilled and unskilled, housewife and none) may have obscured possible differences.

The differences in the occurrence of sleeping disturbances can be explained partly by work times. For example transport workers, construction workers, laborers, and kitchen helpers start their workdays usually early in the morning. Problems may arise if a worker is, eg, a so-called evening-type person or a long sleeper. On the other hand, some workers may tend to go to bed for some reason too early in the evening, and they may thus have difficulty to fall asleep. The amount of physical activity and the psychological factors at work may explain some findings. In our preliminary analyses disturbed nocturnal sleep was associated especially with physically heavy work, while difficulty falling asleep and early morning awakening were complained of proportionally more often by workers with mental strain. The results of these analyses will be presented later in more detail.

The results of this study indicate that occupation should be taken into consideration when the reasons for insomnia are studied in clinical practice or in epi- demiologic studies. In some occupations sleeping disturbances seem to correlate with work conditions, while in some occupations sleeping disturbances seem to be associated with work capacity, economic status, or other variables. Why such differences in sleep disturbances exist between occupations is an interesting question. One explanation could be that there has been some "natural" selection as concerns the vulnerability of the sleep-wake cycle of the workers in different occupations. The study of different factors associated with the sleep-wake cycle in various occupations is important because sleep is necessary for everyone, and disturbed sleep or lack of sleep may contribute to poor work capacity and to risk of accidents at work.

\section{References}

1. Ilmarinen J, Tuomi K, Wägar G, Suurnäkki T, ed. Kunnallisten viranhaltijain ja työntekijäin eläkeikien perusteiden tutkimus [Grounds for the determination of retirement age in municipal occupations]. Institute of Occupational Health, Helsinki 1984, 520 p.

2. Karacan I, Thornby JI, Williams RL. Sleep disturbance: A community survey. In: Guilleminault C, Lugaresi E, ed. Sleep/wake disorders: Natural history, epidemiology, and long-term evolution. Raven Press, New York, NY 1983, pp 37-60. 